\title{
Keeratan Hubungan antara Dimensi Sarang Bambu dan Perkembangbiakan Lebah Trigona sp. Correlation of Bamboo Nest Dimension and Trigona sp. Bee Productivity
}

\author{
Rusli Kapitanhitua, Tekat Dwi Cahyono ${ }^{a *}$, Fitriyanti Kalikya \\ ${ }^{a}$ Fakultas Pertanian Universitas Darussalam Ambon \\ Jl. Waehakila Puncak, Wara Ambon 97128 \\ *Email: tekatdwicahyono@gmail.com
}

Diterima 29 September 2018 Disetujui 19 Desember 2018 Diterbitkan 29 Desember 2018

\begin{abstract}
ABSTRAK
Lebah Trigona sp. merupakan lebah yang tidak memerlukan perhatian khusus selama proses budidaya. Walaupun demikian, naungan, pilihan tempat, dan media untuk budidaya dapat direkayasa untuk meningkatkan produksi madu. Penelitian ini dilakukan untuk mengetahui pengaruh diameter, panjang, dan tebal (dimensi) bambu sebagai media sarang lebah Trigona sp. Sebanyak 54 buah bambu yang telah disiapkan sebagai media sarang budidaya lebah Trigona sp diberi lubang kemudian dimasukkan ratu dan propolis. Bambu yang sudah berisi ratu dan propolis disimpan pada tempat atau rumah yang sudah disiapkan sebagai tempat untuk perkembangbiakan Trigona sp. Setelah 4 bulan, perhitungan hasil madu dilakukan terhadap masing-masing bambu. Hasil penelitian menunjukkan bahwa total produksi madu, campuran madu, propolis, bee bread (MPB) dan bee bread adalah sebesar $221,3 \mathrm{~g}, 792,7 \mathrm{~g}$, dan $33,8 \mathrm{~g}$. Analisis regresi menunjukkan bahwa dimensi bambu yang paling berpengaruh dalam produktivitas Trigona sp. adalah diameter. Diameter bambu berpengaruh pada produksi madu, sedangkan untuk bee bread, berat telur dan MPB tidak signifikan. Penelitian ini menyarankan bahwa bambu dengan kisaran diameter 6-12 cm masih menunjukkan kuantitas madu yang baik.
\end{abstract}

Kata Kunci : bambu, lebah Trigona sp, perkembangbiakan.

\section{ABSTRACT}

The Trigona sp. bees do not require specific breeding treatment. Nevertheless, selection of shade, container or media to cultivate this stingless bee can be engineered to increase the production of honey. This study was aimed to determine the effect of diameter, length, and thickness of bamboo used as a beehive of Trigona sp. The beehive was prepared from 54 thorny bamboo's culms with various sizes. Hole was made on the culms where the queen and propolis could be inserted into the culms. Those inserted culms were then put in the cultivation place. The honey resulted from each culm was calculated after 4 months of the cultivation. The results showed that total honey production, HPB (honey, propolis, bee bread), and bee bread were $221.3 \mathrm{~g}, 792.7 \mathrm{~g}$, and $33.8 \mathrm{~g}$. Regression analysis revealed that there was a significant effect of bamboo's diameter instead of length and thickness on honey production, but not on bee bread, egg's weight and HPB. Recommended diameter of bamboo culms for the cultivation of Trigona sp. was about 6-12 $\mathrm{cm}$ to obtain better quantity of honey.

Keywords : bamboo, cultivation, honey, Trigona sp.

\section{PENDAHULUAN}

Manfaat madu dalam bidang kesehatan tidak diragukan lagi. Madu dihasilkan dari salah satu hewan dari ordo Hymenoptera yaitu lebah. Selain madu, lebah juga menghasilkan polen, royal jelly, propolis, malam lebah, bisa lebah, larva lebah, madu sarang dan roti lebah yang memiliki nilai nutrisi yang tinggi (Jaya, 2017; Suranto, 2007; Usman et al., 2016). Semua produk dari lebah tersebut berpotensi 
dikembangkan kemanfaatannya untuk aspek kehidupan manusia yang lebih luas.

Lebah terbagi menjadi dua kelompok besar, yaitu yang bersengat dan tidak bersengat. Genus Apis merupakan jenis lebah bersengat dan memiliki produktivitas yang baik untuk menghasilkan madu, sedangkan genus Trigona merupakan lebah yang tidak bersengat dan belum banyak dibudidayakan. Alasan utamanya adalah karena menghasilkan madu lebih sedikit dibandingkan dengan genus Apis. Padahal, lebah Trigona memiliki beberapa kelebihan, pertama adalah tidak cepat terfermentasi dan efektif untuk mengobati penyakit asam urat, jantung, asma dan kolesterol yang tinggi (Suranto, 2010). Ranneh et al. (2018) melaporkan bahwa madu Trigona memiliki zat antioksidan yang lebih tinggi dibandingkan dengan madu Apis dorsata. Hasil yang sama juga disajikan oleh Eswaran, Priya \& Bhargava (2015). Kelebihan Trigona yang lain adalah menghasilkan propolis yang sangat baik (Suranto, 2007). Propolis banyak digunakan sebagai obat alam yang sangat bermanfaat untuk kesehatan dan ketahanan tubuh. Bagjavicenna (2008) melaporkan efektifitas propolis Trigona sebagai bahan anti ketombe. Selain itu, propolis Trigona juga efektif sebagai zat anti bakteri (Hasan, Ambarsari, Widjaja, \& Prasetyo, 2014; Goh, 2016), anti mikroba (Chanchao, 2009; Eswaran et al., 2015), anti-emetik (anti mual) (Fikri, Sulaeman, Marliyati \& Fahrudin, 2018), berpotensi sebagai zat antioksidan dan anti kanker (Hasan, Mangunwidjaja, Sunarti, Suparno \& Setiyono, 2014; Kustiawan et al., 2015).

Lebah Trigona tidak membutukan perawatan khusus dan dapat ditempatkan dengan cara digantung di bawah atap rumah atau di pohon rindang (Mahani \& Nurjanah, 2011). Selain itu, bahan sederhana dapat digunakan sebagai sarang seperti kotak kayu, potongan bambu, buah kelapa, tempurung kelapa dan pot tanah asalkan bahan sarang tertutup rapat. Hal ini dimaksudkan untuk menjaga suhu sarang tetap optimal untuk aktivitas Trigona (Ramli et al., 2017). Penelitian yang dilakukan oleh Putra, Watiniasih, \& Suartini (2014) menunjukkan bahwa terdapat perbedaan pola struktur internal sarang pada media berbentuk tabung dan bola. Perbedaannya terjadi pada pola susunan pot madu, pot bee bread dan sel-sel anakan, walaupun masih menunjukkan pola yang sama. Masih menurutnya, sarang berbentuk tabung menghasilkan madu lebih banyak dibandingkan dengan bentuk bola. Bentuk tabung yang dimaksudkan adalah kayu dan bambu, sedangkan bentuk bola adalah menggunakan tempurung kelapa sebagai medianya.

Penelitian terdahulu tentang media perkembangbiakan lebah madu, khususnya di Maluku disajikan oleh Manuhuwa, Loiwatu, Lamberkabel, \& Rumaf (2013). Hasil penelitiannya menunjukkan bahwa bambu duri (Bambusa blumeana) merupakan media perkembangbiakan Trigona sp yang menghasilkan total madu terbanyak dibandingkan dengan dua jenis bambu lain. Namun penelitian tersebut belum menjelaskan pengaruh dimensi bambu terhadap produksi madu. Oleh karena itu, dalam penelitian ini akan dilakukan analisis keeratan hubungan antara dimensi bambu dengan hasil madu. Hasil Penelitian bermanfaat sebagai bahan informasi penting dalam pemilihan diameter bambu yang tepat untuk perkembangbiakan lebah Trigona sp.

\section{BAHAN DAN METODE}

\subsection{Bahan}

Bahan utama yang digunakan dalam penelitian ini adalah koloni Trigona $s p$ dan bambu Duri sebagai media sarang. Bambu dipotong sesuai panjang ruas, berkisar antara 30 dan $60 \mathrm{~cm}$. Diameter bambu yang digunakan adalah $6-12 \mathrm{~cm}$ sedangkan tebal bambunya adalah $0,4-1,1 \mathrm{~cm}$.

\subsection{Metode}

Sebanyak 54 potong bambu duri yang telah disiapkan di ukur panjang, tebal dan diameternya. Pemilihan jenis bambu berdasarkan dua alasan, pertama adalah bambu ini mudah dijumpai di sekitar lokasi penelitian. Yang kedua adalah hasil penelitian terdahulu menunjukkan bahwa bambu duri memberikan hasil madu 


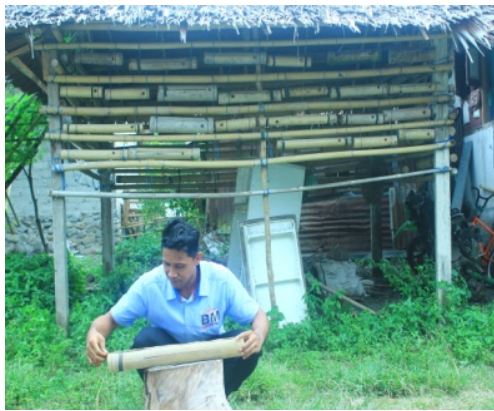

(a)

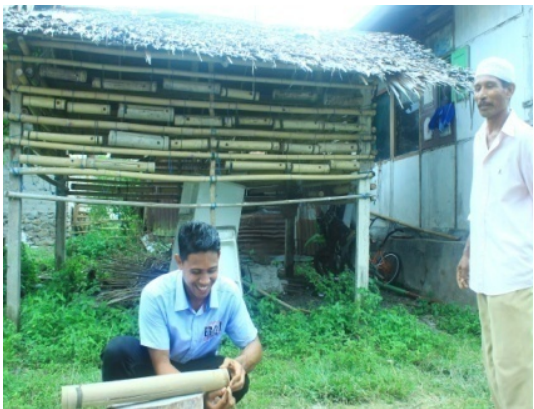

(b)

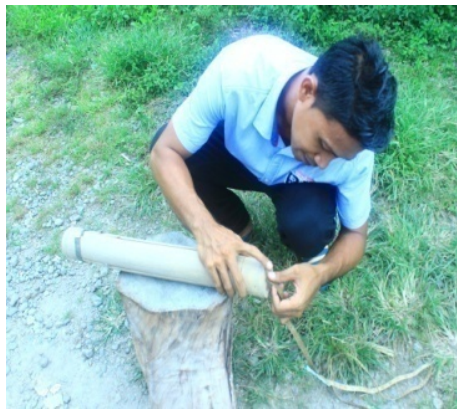

(c)

Gambar 1. Naungan untuk media budidaya lebah Trigona $s p$. di lokasi penelitian, pengukuran panjang (a), keliling (b) dan tebal (c) bambu

dengan produksi terbaik dibandingkan dengan jenis lainnya (Manuhuwa et al., 2013). Langkah berikutnya adalah pembuatan lubang untuk memasukkan ratu dan propolis pada bambu, keduanya merupakan umpan lebah. Ratu dan propolis diambil dari daerah sekitar lokasi penelitian, yaitu di Desa Hila, Kecamatan Leihitu, Kabupaten Maluku Tengah. Ratu dipindahkan dari sarang lebah ke bambu secara langsung, tidak melalui perantara. Menurut Putra \& Jasmi (2016), teknik ini memiliki tingkat keberhasilan sebesar $94,44 \%$. Berikutnya pintu masuk lebah dilumuri propolis dari sarang lama untuk mencegah serangga lain masuk ke dalam bambu.

Bambu yang sudah berisi ratu dan propolis disimpan pada tempat atau rumah yang sudah disiapkan sebagai tempat untuk proses perkembangbiakan Trigona $s p$ (Gambar 1). Setelah 4 bulan, selanjutnya dilakukan pemanenan dan penimbangan hasil produksi yang ditemukan pada tiap bambu. Penimbangan dilakukan terhadap berat madu, propolis, telur dan campuran madu, propolis, bee bread (MPB).

\subsection{Analisis Data}

Analisis data menggunakan regresi linear antara dimensi bambu dengan hasil madu. Model regresinya adalah $Y_{i}=\beta_{0}+\beta_{1}$ $x_{i}+\beta_{2} x_{2}+\beta_{3} x_{3}+e_{i}$ (Mattjik \& Sumertajaya, 2013). Yi adalah produksi lebah madu, $x_{i}=$ panjang bambu, $x_{2}=$ diameter bambu, $x_{3}=$ tebal bambu, $e_{i}=$ galat.

\section{HASIL DAN PEMBAHASAN}

\subsection{Aspek Budidaya Lebah Trigona sp}

Lebah Trigona sp. hanya membutuhkan naungan sederhana untuk aktivitasnya. Aktivitas mencari polen dan nektar paling aktif dilakukan pada siang hari sekitar pukul 10.00 sampai 12.00 dan semakin menurun hingga sore hari (Nugroho \& Soesilohadi, 2015; Salatnaya, 2012). Pada saat puncak aktivitas, tercatat lebah masuk atau keluar sarang sebanyak 43 atau 46 kali per 5 menit (Salim, Agus, Umami, \& Budisatria, 2017). Sementara itu, sarang yang digunakan bisa menggunakan kayu sengon dan kayu lapis (Ismawan, Septiani, Haridanto, \& Anggrani, 2013), bambu, rangka besi dan tempurung kelapa (Putra et al., 2014; Awan, 2017).

Suhu, kelembaban, intensitas cahaya dan kecepatan angin adalah faktor penting dalam budidaya lebah Trigona (do Nascimento \& Nascimento, 2012; Putra, 2013). Suhu normal yang terdapat di Desa Hila, tempat penelitian berlangsung, berkisar antara $26-34^{\circ} \mathrm{C}$ dengan suhu ratarata sebesar $25,5^{\circ} \mathrm{C}$ (Tabel 1). Suhu ideal untuk lebah beraktivitas adalah $16-26^{\circ} \mathrm{C}$, sehingga suhu di Desa Hila relatif sesuai dengan kebutuhan Trigona dalam beraktivitas. Salatnaya (2012) menambahkan bahwa aktivitas lebah dimulai pada saat suhu berkisar antara 22$23^{\circ} \mathrm{C}$ dengan kelembaban $70-88 \%$, dan intensitas cahaya 183-4344 lux. Aktivitas tertinggi terjadi pada saat suhu mencapai $26-28^{\circ} \mathrm{C}$, kelembaban $55-71 \%$, dan intensitas cahaya 46.875-91.347 lux. Saat suhu sangat tinggi, di atas $33^{\circ} \mathrm{C}$, lebah 
akan mengepak sayapnya untuk menurunkan suhu tubuhnya (Amano, 2004). Mekanisme ini akan menimbulkan suara dengungan yang agak keras di dalam sarang. Oleh karena itu, modifikasi tipe sarang diperlukan agar suhu tertinggi tidak melebihi $33^{\circ} \mathrm{C}$ dan tidak menurunkan kualitas propolis (Basrawi, Hamid, Bahari, Noordin, \& Yusof, 2017).

Madu lebah Trigona dapat dipanen 3 sampai 4 kali dalam setahun. Pada penelitian ini panen dilakukan setelah 4 bulan. Jika waktunya terlalu singkat, maka produksi madu belum maksimal, sebaliknya jika terlalu lama maka lebah dan koloninya berpotensi untuk meninggalkan sarang karena telah penuh dan terjadi kenaikan suhu di dalam sarang. Salah satu indikator lainnya saat sarang sudah penuh dan siap dipanen ditandai dengan lebah yang lebih agresif (Amano, 2004; Hafizuddin, 2015).
Pemanenan dilakukan dengan pisau untuk memisahkan bagian-bagian yang akan ditimbang sebagai variabel penelitian.

Selain madu, produk lain yang ditemukan di dalam sarang lebah bambu adalah telur Trigona, bee bread dan propolis. Putra et al. (2014) menjelaskan bahwa di dalam sarang lebah bambu terdapat pot madu, pot bee bread dan pot sel-sel anakan yang dihubungkan oleh batumen. Polanya sesudah internal corong pintu adalah pot madu, pot bee bread dan sel-sel anakan. Telur Trigona mudah dipisahkan, ditimbang langsung, dan dikembalikan sesuai kebutuhan. Bee bread juga mudah dipisahkan dan ditimbang. Propolis bergabung dengan bagian yang lain sehingga ditimbang dalam bentuk MPB (madu, propolis dan bee bread). Rerata dimensi bambu, jumlah madu dan produk lain yang dihasilkan di dalam sarang bambu disajikan pada Gambar 2.

Tabel 1. Suhu dan Presipitasi di Hila (Tahun 2016)

\begin{tabular}{lrrrrrrrrrrrr}
\hline Bulan & Jan & Feb & Mar & Apr & Mei & Jun & Jul & Ags & Sept & Okt & Nov & Des \\
\hline Suhu rata-rata $\left({ }^{\circ} \mathrm{C}\right)$ & 26,3 & 26,1 & 26,1 & 26 & 25,3 & 24,6 & 24,1 & 24,1 & 24,9 & 25,6 & 26,7 & 26,7 \\
Suhu terendah $\left({ }^{\circ} \mathrm{C}\right)$ & 23,1 & 22,8 & 22,5 & 22,3 & 21,8 & 21,1 & 20,5 & 20 & 20,3 & 20,7 & 22,3 & 22,9 \\
Suhu tertinggi $\left({ }^{\circ} \mathrm{C}\right)$ & 29,5 & 29,4 & 29,7 & 29,7 & 28,9 & 28,2 & 27,8 & 28,2 & 29,5 & 30,6 & 31,2 & 30,5 \\
Presipitasi $(\mathrm{mm})$ & 146 & 144 & 152 & 188 & 205 & 115 & 62 & 17 & 10 & 23 & 63 & 159 \\
\hline
\end{tabular}

Sumber: Stasiun Klimatologi Kota Ambon dan https://id,climate-data,org/location/598816/

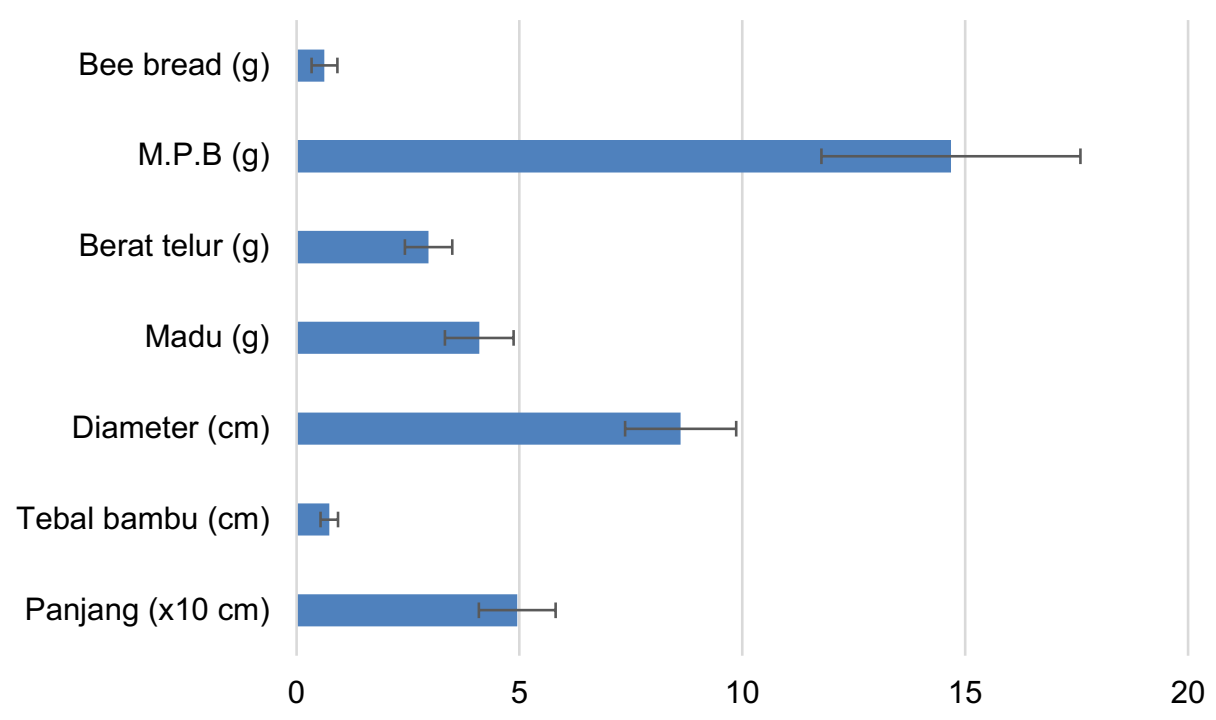

Gambar 2. Rerata Dimensi Sarang Bambu, Jumlah Madu dan Produk Lainnya 
Tabel 2. Anova Regresi antara Produksi Madu dengan Dimensi Bambu

\begin{tabular}{lrrrrr}
\hline & $D f$ & $S S$ & $M S$ & $F$ & Significance $F$ \\
\hline Regression & 3 & 6,077 & 2,026 & 3,989 & 0,0127 \\
Residual & 50 & 25,393 & 0,508 & & \\
Total & 53 & 31,470 & & & \\
\hline
\end{tabular}

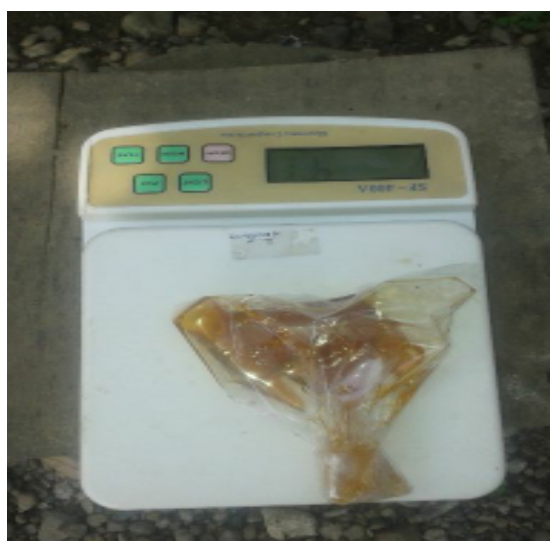

Gambar 3. Madu yang Sudah Dipisahkan

\subsection{Madu}

Warna madu Trigona hasil budidaya selama penelitian adalah kuning agak kecokelatan dan sedikit keruh (Gambar 3). Intensitas warna merupakan salah satu indikator kandungan senyawa fenolik dari madu (Kek, Chin, Yusof, Tan, \& Chua, 2014). Selanjutnya hasil penelitian menunjukkan bahwa berat madu berkisar antara 2,6 - 5,7 g pada tiap sarang bambu. Produksi madu selama penelitian adalah $221,3 \mathrm{~g}$ dengan rata-rata sebesar 4,1 $\mathrm{g}$ tiap sarang (Gambar 2). Total produksi madu hasil penelitian ini hasilnya tidak jauh berbeda dengan hasil penelitian terdahulu oleh Manuhuwa et al. (2013) yang menunjukkan total produksi madunya sebesar $231,69 \mathrm{~g}$. Hal ini erat kaitannya dengan lokasi penelitian dilakukan di desa yang sama dengan penelitian ini. Sebagai bahan perbandingan, Siregar, Fuah \& Octavianty (2011) menyajikan data produksi madu koloni lebah Trigona $6,5 \mathrm{~kg}$ per tahun. Selanjutnya setelah dianalisis dengan regresi, persamaan regresinya ditunjukkan oleh Persamaan 1.

Madu $=6,85-0,01 p-0,58 t-0,20 d$

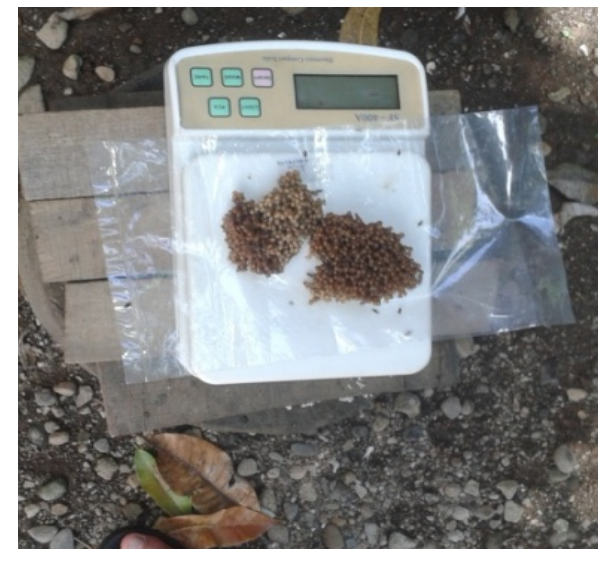

Gambar 4. Telur Trigona

Nilai Significance $F(S F)$ sebesar 0,012 (Tabel 2) menunjukkan bahwa ada hubungan antara dimensi bambu dengan total produksi madu, meskipun nilai koefisien determinasinya masih relatif kecil $\left(R^{2}=0,193\right)$. Menurut Putra et al. (2014), semakin besar diameter bambu semakin besar produksi madu dihasilkan. Selanjutnya dari ketiga dimensi bambu yang diukur, maka diameter bambu memiliki korelasi yang lebih baik dibandingkan dengan panjang dan tebal bambu. Hal ini ditunjukkan dengan nilai $P=0,022$.

\subsection{Berat Telur}

Telur lebah berbentuk bulat dengan diameter yang berbeda-beda tergantung jenisnya. Fase telur untuk semua strata (ratu, pekerja, jantan) adalah 3 hari. Selanjutnya akan masuk pada fase larva yang memiliki umur yang berbeda untuk tiap strata. Telur lebah Trigona dihasilkan oleh ratu lebah dan pekerja. Perbedaannya adalah pekerja tidak dapat menghasilkan telur betina karena tidak memiliki spermatecha untuk menampung sperma. Telur dan anakan selalu tersedia di dalam sarang sehingga penting diketahui produksinya saat tiba siklus pemanenan (Rahman \& Singh, 1940). 
Berat telur saat pengamatan berkisar antara 2,0-3,7 g dan total jumlah produksi sebanyak 159,9 g. Bentuknya dapat dilihat pada Gambar 4. Setelah dianalisis dengan regresi, persamaannya seperti pada Persamaan 2.

Berat telur $=3,77-0,01 p-0,59 t+0,03 d$ (2)

Tabel 3 menunjukkan bahwa nilai significance factor sebesar 0,282 dan $R^{2}=0,072$. Ini menunjukan bahwa berat telur tidak dipengaruhi oleh panjang, keliling dan juga tebal bambu. Pernyataan ini diperkuat dengan nilai koefisien determinasi yang sangat kecil.

\subsection{Bee bread}

Produksi bee bread dihasilkan dari lebah Trigona sebagai bahan pakan ratu. Produksi bee bread sangat tergantung pada ketersediaan pakan atau tanaman berbunga yang ada disekitar lokasi. Produksi bee bread dari lebah Trigona $s p$ memperlihatkan warna kekuning-kuningan dan berbentuk bulat (Gambar 5). Bee bread diproduksi oleh lebah pekerja yang diprioritaskan sebagai makanan utama ratu. Penyebabnya adalah ratu hanya mampu menghasilkan telur dan tidak mempunyai kemampuan lainnya, termasuk mencari makan. Bahkan untuk mengeluarkan telur dari perutnya pun harus dibantu oleh lebah pekerja (Mahani \& Nurjanah, 2011).

Lebah pekerja mendapatkan sumber makanan yang layak, jika tersedia tanaman pendukung di sekitar lokasi budidaya. Lemerkabel (2007) menjelaskan bahwa di sekitar lokasi budidaya ditemukan tanaman bintanggur, ketapang, nangka, sukun dan beberapa tanaman lain sumber makanan lebah. Masa berbunga beberapa tanaman tersebut berbeda, sehingga dapat dikatakan sumber makanan lebah tersedia sepanjang tahun. Ketersediaan sumber makanan mendukung produktivitas lebah dan berpotensi meningkatkan produksi propolis (Salatnaya, 2012).

Hasil penelitian menunjukkan bahwa kisaran Bee bread adalah 0,1 - 1,2 g dengan total jumlah produksi sebanyak 33,8 $\mathrm{g}$, dan rata-ratanya sebesar $0,63 \mathrm{~g}$. Sebagai perbandingan, Manuhuwa et al. (2013) menyajikan total produksi sebesar $25,21 \mathrm{~g}$. Hasil analisis regresi adalah pada Persamaan 3.

$$
\begin{aligned}
\text { Bee bread }= & 0,881-0,002 p+0,132 t- \\
& 0,030 d(3)
\end{aligned}
$$

Tabel 3. Anova Regresi antara Berat Telur dengan Dimensi Bambu

\begin{tabular}{lrrrrr}
\hline & $d f$ & $S S$ & $M S$ & $F$ & Significance $F$ \\
\hline Regression & 3 & 1,091 & 0,364 & 1,310 & 0,282 \\
Residual & 50 & 13,878 & 0,278 & & \\
Total & 53 & 14,968 & & & \\
\hline
\end{tabular}

Tabel 4. Anova Regresi antara Bee bread dengan Dimensi Bambu

\begin{tabular}{lrrrrr}
\hline & $d f$ & $S S$ & $M S$ & $F$ & Significance $F$ \\
\hline Regression & 3 & 0,129 & 0,043 & 0,496 & 0,686 \\
Residual & 50 & 4,315 & 0,086 & & \\
Total & 53 & 4,444 & & & \\
\hline
\end{tabular}

Tabel 5. Anova Regresi antara Bee Bread dengan Dimensi Bambu

\begin{tabular}{lrrrrr}
\hline & $d f$ & $S S$ & $M S$ & $F$ & Significance $F$ \\
\hline Regression & 3 & 5,254 & 1,751 & 0,198 & 0,897 \\
Residual & 50 & 442,153 & 8,843 & & \\
Total & 53 & 447,408 & & & \\
\hline
\end{tabular}




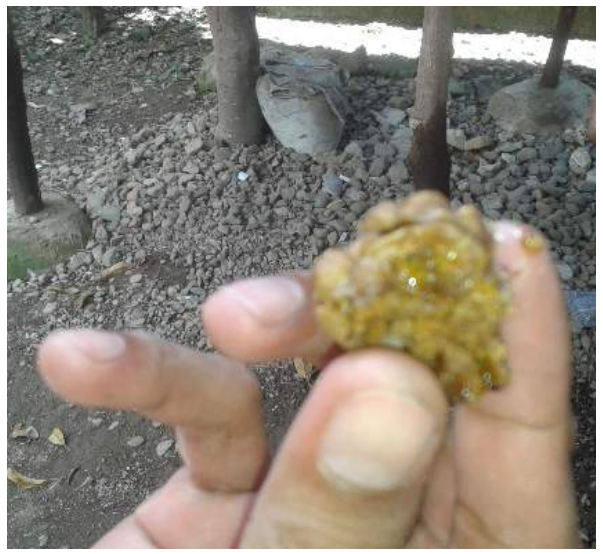

Gambar 5. Bee Bread Trigona

Bee bread tidak dipengaruhi oleh dimensi bambu (panjang, tebal dan diameter). Hal ini ditunjukkan dengan nilai $F$ yang kecil (Tabel 4). Nilai determinasi yang kecil $\left(R^{2}=0,02\right)$ semakin menegaskan hal tersebut.

\subsection{Madu, Propolis, Bee Bread (MPB)}

Kantung madu dan bee pollen letaknya berdampingan, sedangkan kantung atau bola sarang itu sendiri adalah propolis padat. Kantung madu lebah Trigona berwarna cokelat kehitaman, sedangkan warna propolisnya berwarna kecokelatan dan warna dari roti lebahnya berwarna kuning. Saat pemanenan, ketiga bahan yang sangat bermanfaat bagi kesehatan itu bercampur menjadi satu dan tidak mudah untuk dipisahkan. Oleh karena itu, madu, propolis dan bee bread pada peneltian ini ditimbang secara bersamaan (Gambar 6).

Hasil MPB berkisar antara 10,2 $19,1 \mathrm{~g}$ dan jumlah total produksi adalah 792,7 g. Rata-rata pegamatan sebesar 14,68 g. Rumus regresi antara MPB dan dimensi bambu pada Persamaan 4 .

$M P B=12,553-0,003 p+0,139 t+0,254 d$ (4)

Nilai SF sebesar 0,897 (terlihat pada Tabel 5) dan $R^{2}=0,012$ menunjukkan bahwa MPB tidak dipengaruhi oleh dimensi bambu. Koefisian determinasinya terlalu kecil untuk menjelaskan pengaruh keduanya. Potensi meningkatnya hasil madu dengan semakin besarnya diameter

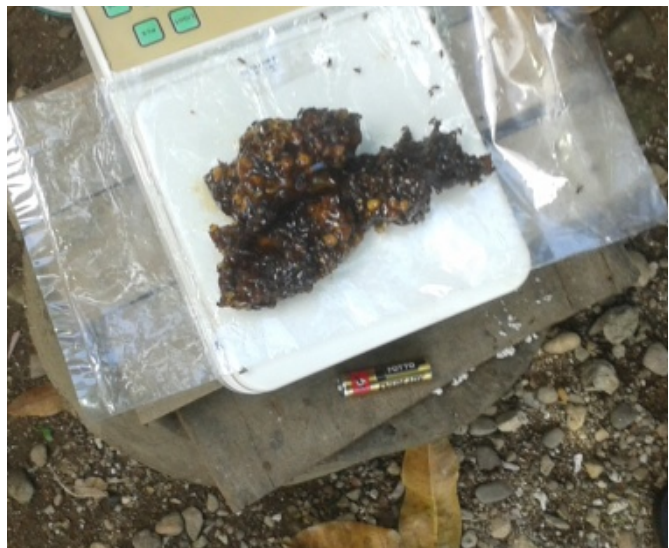

Gambar 6. MPB Trigona

bambu telah dijelaskan dengan Persamaan 1. Pernyataan pendukung lainnya dilaporkan oleh Putra et al. (2014) dan (Manuhuwa et al., 2013). Pebedaan justru terjadi pada MPB yang ditimbang secara bersamaan. Hal ini terjadi karena MPB terdiri dari 3 komponen yang digabungkan, apabila diukur secara terpisah tentunya masing-masing faktor berkontribusi.

Keeratan hubungan antara dimensi bambu (panjang, tebal dan lebar) dengan madu, berat telur, bee bread dan MPB telah disajikan pada Persamaan 1 sampai dengan 4. Produksi madu erat hubungannya dengan diameter bambu, sementara berat telur, bee bread dan MPB tidak berkorelasi, baik dengan diameter, panjang dan tebalnya. Selisih diameter yang digunakan pada penelitian ini mampu menjelaskan perbedaan produksi madu. Secara umum, semakin besar diameter akan meningkatkan produksi madu, namun jika terlalu besar kemungkinannya adalah masih banyak ruang kosong dan kemungkinan tidak didatangi oleh lebah pekerja. Kisaran diameter pada peneltian ini terbukti memberikan hasil madu yang baik, sampai diameter terbesar yang digunakan yaitu $11,8 \mathrm{~cm}$. Hal ini tentunya melengkapi saran dari penelitian terdahulu bahwa diameter bambu yang digunakan berada dalam rentang 6-10 cm (Manuhuwa et al., 2013). 


\section{KESIMPULAN DAN SARAN}

Kesimpulan yang dapat diambil dari penelitian ini adalah total produksi madu, propolis (MPB) dan bee bread selama penelitian masing-masing adalah sebesar $221,3 \mathrm{~g}, 792,7 \mathrm{~g}$, dan 33,8 g. Berikutnya hasil analisis regresi menunjukan bahwa dimensi bambu, khususnya diameter berpengaruh pada produksi madu, sedangkan untuk bee bread, berat telur dan MPB tidak signifikan. Tidak ditemukan korelasi antara Panjang dan tebal bamboo terhadap produksi madu, bee bread, berat telur, dan MPB. Penelitian ini menyarankan agar penetapan bambu dengan kisaran diameter 6-12 cm masih layak digunakan sebagai media sarang Trigona sp untuk mendapatkan jumlah madu yang baik.

\section{DAFTAR PUSTAKA}

Agussalim, A., Agus, A., Umami, N., \& Budisatria, I. G. S. (2017). The Effect of Daily Activities Stingless Bees of Trigona sp. on Honey Production. Paper presented at The International Seminar on Tropical Animal Production, (pp. 223-227). Yogyakarta: Fakultas Peternakan Universitas Gadjah Mada.

Amano, K. (2004). Attempts to Introduce Stingless Bees for The Pollination of Crops Under Greenhouse Conditions in Japan. Japan: Food and Fertilizer Technology Center.

Awan, A. (2017). The Production of Propolis, Bee Bread, Bee Wax and Honey of Stingless Bee (Trigona Spp) on Various Hive's Mediums in West District of Seram. Paper presented at the Proceeding The 2nd International Seminar on Education 2017.

Bagjavicenna, E. (2008). Potensi Propolis Lebah Trigona spp sebagai Bahan Antimikroba Ketombe (Skripsi). Bogor: Institut Pertanian Bogor.

Basrawi, F., Hamid, A. R. A., Bahari, R., Noordin, M. N. M., \& Yusof, M. H. (2017). A Preliminary Study on the Thermal Performance of a Ventilated Honey Cassette for Stingless Bees.
Paper presented at the MATEC Web of Conferences.

Chanchao, C. (2009). Antimicrobial Activity by Trigona laeviceps (stingless bee) Honey from Thailand. Pakistan Journal of Medical Science, 25(3), 364-369.

do Nascimento, D. L., \& Nascimento, F. S. (2012). Extreme Effects of Season on The Foraging Activities and Colony Productivity of A Stingless Bee (Melipona asilvai Moure, 1971) in Northeast Brazil. Psyche: A Journal of Entomology, 2012, 1-6.

Eswaran, V. K. V. U., Priya, V., \& Bhargava, H. R. (2015). A Comparative Study of The Biochemical, Antioxidative and Anti-microbial Activity of Apis and Trigona Honey Collected from Different Geographical Areas of India. World Applied Sciences Journal, 33(1), 160-167.

Fikri, A., Sulaeman, A., Marliyati, S. A., \& Fahrudin, M. (2018). Antiemetic Activity of Trigona spp. Propolis from Three Provinces of Indonesia with Two Methods of Extraction. Pharmacognosy Journal, 10(1), 120122.

Goh, J. S. J. (2016). Physicochemical Properties and In-Vitro Inhibitory Effects of Stingless Bee (Trigona Spp.) Honey Against Escherichia Coli. Perak, Malaysia: Universiti Tunku Abdul Rahman.

Hafizuddin, M. Y. (2015). Harvesting Method of Stingless Bee Honey (trigona sp) (Undergraduate Final Project Report). Malaysia: Faculty of Agro Based Industry, Universiti Malaysia Kelantan.

Hasan, A. E. Z., Ambarsari, L., Widjaja, W. K., \& Prasetyo, R. (2014). Potency of Nanopropolis Stinglessbee Trigona spp Indonesia as Antibacterial Agent. IOSR Journal of Pharmacy, 4(12), 0109.

Hasan, A. E. Z., Mangunwidjaja, D., Sunarti, T. C., Suparno, O., \& Setiyono, A. 
(2014). Investigating The Antioxidant and Anticytotoxic Activitiesof Propolis Collected from Five Regions of Indonesia and Their Abilities to Induce Apoptosis. Emirates Journal of Food and Agriculture, 26(5), 390-398.

Ismawan, R., Septiani, A., Haridanto, O., \& Anggrani, H. (2013). Pemanfaatan Kayu Sengon dan Kayu Lapis sebagai Alternatif Bahan Kandang Lebah Trigona Laeviceps untuk Mengoptimalkan Produksi Propolis dan Mengefisiensikan Biaya Produksi (Skripsi). Bogor: Institut Pertanian Bogor.

Jaya, F. (2017). Produk-produk Lebah Madu dan Hasil Olahannya. Malang, Indonesia: Universitas Brawijaya Press.

Kek, S. P., Chin, N. L., Yusof, Y. A., Tan, S. W., \& Chua, L. S. (2014). Total Phenolic Contents and Colour Intensity of Malaysian Honeys from The Apis spp. and Trigona spp. Bees. Agriculture and Agricultural Science Procedia, 2, 150-155.

Kustiawan, P. M., Phuwapraisirisan, P., Puthong, S., Palaga, T., Arung, E. T., \& Chanchao, C. (2015). Propolis from The Stingless Bee Trigona incisa from East Kalimantan, Indonesia, Induces In Vitro Cytotoxicity and Apoptosis in Cancer Cell Lines. Asian Pacific Journal of Cancer Prevention, 16(15), 6581-6589.

Lemerkabel, J. (2007). Laporan Perkembangan Lebah Madu di Provinsi Maluku (Laporan Tahunan Asosiasi Perlebahan Indonesia) Ambon. Ambon, Indonesia: Asosisasi Perlebahan Indonesia.

Mahani, R., \& Nurjanah, N. (2011). Keajaiban Propolis Trigona. Jakarta: Pustaka Bunda.

Manuhuwa, E., Loiwatu, M., Lamberkabel, J. S. A., \& Rumaf, I. (2013). Produksi Madu, Propolis dan Roti Lebah Tanpa Sengat (Trigona spp) dalam Sarang Bambu. Paper presented at the
Seminar Masyarakat Peneliti Kayu XVI, Balikpapan.

Mattjik, A. A., \& Sumertajaya, M. (2013). Perancangan Percobaan dengan Aplikasi SAS dan Minitab. Bogor: PT Penerbit IPB Press.

Nugroho, R. B., \& Soesilohadi, R. H. (2015). Aktivitas Mencari Makan Lebah Pekerja, Trigona sp (Hymenoptera: Apidae) di Gunungkidul. Biomedika, 8(1), 37-41.

Putra, D. P., \& Jasmi, J. (2016). Teknik Perbanyakan Koloni Trigona spp ke Sarang Buatan (Stup). UNES Journal of Scientech Research, 1(2), 11-19.

Putra, H. (2013). Pengaruh Manajemen Naungan Stup terhadap Aktivitas Terbang Galo-galo (Trigona drescheri) di Sumanik Sumatera Barat (Skripsi). Bogor: Institut Pertanian Bogor.

Putra, P. A. H., Watiniasih, N. L., \& Suartini, N. M. (2014). Struktur dan Produksi Lebah Trigona spp. pada Sarang Berbentuk Tabung dan Bola. Jurnal Biologi, 18(2), 60-64.

Rahman, K. A., \& Singh, S. (1940). Beekeeping in India. Indian Farming, 1, 10-17.

Ramli, A. S., Luqman, A., Basrawi, F., Oumer, A. N., Aziz, A. A., \& Mustafa, Z. (2017). A New Cooling Technique for Stingless Bees Hive. Paper presented at the MATEC Web of Conferences.

Ranneh, Y., Ali, F., Zarei, M., Akim, A. M., Hamid, H. A., \& Khazaai, H. (2018). Malaysian Stingless Bee and Tualang Honeys: A Comparative Characterization of Total Antioxidant Capacity and Phenolic Profile Using Liquid Chromatography-Mass Spectrometry. LWT-Food Science and Technology, 89, 1-9.

Salatnaya, H. (2012). Productivity of Trigona spp. as a Propolis Producer at Monoculture and Policulture Nutmeg Plantation in East Java (Tesis). Bogor: Institut Pertanian Bogor. 
Siregar, H. C., Fuah, A. M., \& Octavianty, Y. (2011). Propolis; Madu Multikhasiat. Jakarta: Penebar Swadaya Grup.

Suranto, A. (2010). Dahsyatnya Propolis untuk Menggempur Penyakit. Jakarta: PT Agro Media Pustaka.

Suranto, A. (2007). Terapi Madu. Jakarta: Penebar Swadaya.

Usman, A. N., Syam, Y., Natzir, R., Rahardjo, S. P., Hatta, M., Raya, I., Widaningsih, Y., Abdullah A. Z., \& Ainurafiq. (2016). Nutrient Content and $\mathrm{pH}$ of Honey Propolis Trigona from Masamba, South Sulawesi Indonesia. International Journal of Sciences: Basic and Applied Research, 26(3), 246-251. 